\title{
Chromosome specific c-DNA libraries: reduction of unspecific priming events by purification of heteronuclear RNA
}

\author{
Pierre J.L. Lagoda ${ }^{1}$, Jeff M. Trent ${ }^{2}$ \& Eckart U. Meese ${ }^{3 *}$ \\ ${ }^{l}$ CIRAD-BIOTROP AGETROP B.P. 503524032 Montpellier, France; ${ }^{2}$ Division of Cancer Biology, \\ Departments of Radiation Oncology and Human Genetics, University of Michigan Medical Center, \\ MSRBII, C560, 1120 West Medical Center Drive, Ann Arbor, MI 48109, USA; ${ }^{3}$ Department of \\ Human Genetics, Medical School, University of Saar, Bau 68, Homburg/Saar, Germany; *Author for \\ correspondence
}

Received 15 June 1993; accepted in revised form 27 September 1993

Key words: hnRNA, hncDNA, Alu, human chromosomes

\begin{abstract}
Chromosome specific c-DNA libraries greatly facilitate the isolation of disease associated genes which have been previously linked to particular chromosomes. Recently, several methods have been developed and employed for the isolation of transcribed sequences from specific human chromosomes and chromosome regions. Heteronuclear (hn) RNA from somatic human/rodent cell hybrids has been used as starting material to selectively prime the synthesis of human specific c-DNAs. A drawback of this method is the high number of rodent clones found in these chromosome specific c-DNA libraries. Here, we provide direct evidence that unspecific priming events account for the majority of these rodent clones. Using an Alu consensus primer hn-RNA human specific c-DNA libraries have been established and the specificity of Alu-priming has been evaluated. Using a variety of purification schemes for isolating hn-RNA we have significantly reduced the percentage of unspecific priming events. We also included a comparison of the hn-RNA yield from different somatic hybrids prior and after purification.
\end{abstract}

\section{Introduction}

The generation of chromosome region specific c-DNA libraries facilitates the isolation of genes involved in human diseases. Recently, several approaches have been developed to clone expressed sequences from somatic cell hybrids which contain a specific human chromosome or chromosome fragment in a rodent background. Jones et al. (1992) applied subtractive c-DNAhybridization to isolate c-DNAs from a human/ rat hybrid retaining a fragment from chromosome 17 [1]. Oligo-(dT)-primed c-DNA fragments from this somatic cell hybrid containing the chromosome region of interest were hybridized with an excess of RNA from a second somatic cell hybrid missing the fragments of interest. Subtractive hybridization was shown to yield c-DNA clones encoded within defined chromosome region.

Two additional recent methods make use of unspliced messenger RNA (hn-RNA) which retains species specific repetitive sequences. Liu and coworkers generated c-DNA libraries using a consensus $5^{\prime}$ intron splice sequence which is present in hn-RNA but not in mature RNA [2]. 
Subsequently, the c-DNA library was screened with total human DNA. In a similar approach Alu consensus sequences have been applied as a primer for c-DNA synthesis [3]. Hn-RNA which has been used as template contains Alusequences in introns and 3 'untranslated regions. Priming with Alu-sequences, c-DNA-synthesis is initiated predominately from the human components of human/rodent somatic cell hybrids. Most recently Alu-PCR was employed for the construction of a hncDNA library of human $12 p$ transcripts isolated from a somatic cell hybrid [4].

Accordingly, hn-RNA Alu-primed c-DNA libraries have now been established from several human/rodent somatic cell hybrids, and have proven of significant value in identifying expressed sequences within defined chromosomal regions. A common problem to these libraries is, however, the amount of rodent hn-cDNA clones. To increase the number of human specific c-DNA clones within these libraries we have analyzed several different methods for hn-RNA purification.

\section{Materials and methods}

\section{Human-rodent somatic cell hybrids}

MCH262A1D6 (generated by E. Stanbridge) contains an entire human chromosomes 6 , and portions of human chromosomes 9 and 15 in a mouse background [5]. MCH381.2D is a radiation reduction hybrid of MCH626-A1D6 containing del(6)(q16q23) in a mouse background [5]. D113JA retains the human chromosome 6 which was isolated from MCH262A1D6 by microcell mediated chromosome transfer [6]. GM1OO27 and GM10888 which were obtained from Coriell Institute Camden, $\mathrm{NJ}$, contain human chromosome 22 in a hamster background.

\section{Isolation of nuclei}

Sub confluently grown monolayers of hybrid cells were harvested as follows. Cells were rinsed 2 times in RNase-free PBS at room temperature and incubated $1-2 \mathrm{~min}$ at $37^{\circ} \mathrm{C}$ in $10 \mathrm{ml}$ trypsinEDTA (trypsin $0.05 \%(\mathrm{w} / \mathrm{v}) ;$ EDTA $0.02 \%$ $(w / v))$. Subsequently, cells were collected by centrifugation $(500 \mathrm{~g})$ at $4{ }^{\circ} \mathrm{C}$ for $5 \mathrm{~min}$. Lysis buffer (Tris- $\mathrm{HCl} 10 \mathrm{mM}, \mathrm{pH} 8 ; \mathrm{NaCl} 10 \mathrm{mM}$; $\mathrm{MgCl}_{2} 3 \mathrm{mM}$; NP-40 0.5\% (w/v); Vanadyl Ribonucleoside Complex $10 \mathrm{mM}$ ) was gradually added under gently vortexing to a final volume of $4 \mathrm{ml}$. The cell-suspension was incubated on ice for $5 \mathrm{~min}$. Nuclei were controlled and counted by phase contrast microcospy prior to being pelleted by centrifugation $(500 \mathrm{~g})$ at $4{ }^{\circ} \mathrm{C}$ for $5 \mathrm{~min}$.

\section{Isolation of $h n R N A$}

Hn-RNA was isolated using the RNAzol ${ }^{\mathrm{TM}}$ method [7]. Briefly, up to $10^{7}$ nuclei were homogenized in $2 \mathrm{ml}$ of a guanidinium thiocyanate/phenol solution. RNA was extracted by adding 0.1 volume of $\mathrm{CHCl}_{3}$. After precipitation by isopropanol, the RNA pellet was washed with $75 \%$ ethanol in DEPC treated double distilled water. RNA concentration was determined by spectrophotometry and RNA quality was assayed by agarose gel electrophoresis.

\section{RNA-purification}

RNA was purified by $\mathrm{CsCl}$ gradientcentrifugation as described in Sambrook et al. 1990 [8]. Briefly, RNA was pelleted by centrifugation at $40000 \mathrm{rpm}$ at $20^{\circ} \mathrm{C}$ for $12 \mathrm{~h}$ in a SW60 rotor. Alternatively, RNA was purified by Oligo-(dT)-chromatography using the mRNA purification kit from Boehringer Mannheim [9]. RNA was heat-denatured in TE buffer $(10 \mathrm{mM}$ Tris; $1 \mathrm{mM}$ EDTA; $\mathrm{pH} 8)$ at $65^{\circ} \mathrm{C}$ and subsequently diluted with binding buffer $(1 \mathrm{M} \mathrm{NaCl}$; 40 mM Tris; 2 mM EDTA; $0.2 \%$ (w/v) N-lauroylsarcosine; $\mathrm{pH} 7.4)$. The denatured RNA solution was mixed with dry oligo-(dT)-cellulose, the RNA/oligo-(dT)-slurry transferred to a column, non-polyadenylated RNA removed by washing with $(0.5 \mathrm{M} \mathrm{NaCl} ; 20 \mathrm{mM}$ Tris; $1 \mathrm{mM}$ EDTA; $0.1 \%(\mathrm{w} / \mathrm{v})$ N-lauroylsarcosine; $\mathrm{pH} 7.4)$ and poly(A)-hnRNA eluted with TE buffer. This eluted hn-RNA was passed through an oligo(dT)-cellulose column a second time. 
Transcription of hn-RNA into c-DNA

Transcription of hn-RNA $(5 \mu \mathrm{g} / 20 \mu \mathrm{l})$ was performed according to the method of Gubler and Hoffman [10] using the cDNA synthesis kit from Boehringer Mannheim. First strand synthesis was performed at $42{ }^{\circ} \mathrm{C}$ using an oligo- $(\mathrm{dT})_{15}$ or random primer $\mathrm{p}(\mathrm{dN})_{6}$, respectively. Alternatively, we used Alu consensus primer A1 (5' AAACTCTACCTCAGAGCG-3') $(1.5 \mu \mathrm{g} / 20 \mu \mathrm{l}$ $[14 \mu \mathrm{M}])$ to initiate cDNA synthesis at the $3^{\prime}$ end of Alu-sequences within hnRNA templates [11]. Second strand synthesis was initiated by RNAse $H$ treatment. The yield of synthesis product was determined by Cherenkov-counting assaying the amount of ${ }^{32} \mathrm{P}-\mathrm{dCTP}$ incorporated into TCA-precipitable material.

\section{Results and discussion}

Hn-RNA was prepared from somatic cell hybrids which retained specific human chromosomes in a rodent background. Nuclei were isolated to enrich for immature hn-RNA. The nuclei preparation was controlled by microscopy. Hn-RNA isolation was carried out by the RNA$\mathrm{zol}^{\mathrm{TM}}$ method as described in the Material and methods section.

The amount of total hn-RNA varied depending on the specific somatic cell hybrid. Factors which influenced the yield of RNA included the number and size of rodent and human chromosomes, and the expression status. We utilized five different hybrids to determine the maximal yield of hn-RNA. On average, we isolated $65 \mu \mathrm{g} \mathrm{hn-}$ RNA from $5 \times 10^{6}$ subconfluently grown cells. The lowest yield $(42 \mu \mathrm{g})$ was obtained from hybrid MCH262A1D6 which contains an entire chromosome 6 and portions of chromosome 9 and 15 against a mouse background. The highest yield was obtained from hybrid MCH381.2D which contains del(6)q21-23 in mouse background. The precise yield for each hybrid is given in Table 1.

Starting from hn-RNA c-DNA-synthesis was performed. Human specific primer sequences favor c-DNA synthesis from human chromosomes over synthesis from rodent chromosomes. We used an Alu-consensus sequence (A1) which was shown to bind specifically to human DNA $[11,12]$. Starting from hybrid MCH262A1D6 we obtained $80 \mathrm{ng}$ first strand c-DNA from $5 \mu \mathrm{g}$ hn-RNA (Table 2).

To asses the specificity of the Alu primed c-DNA the synthesis was carried out without any primer. As indicated in Table 2 we found $16 \%$ of the Alu-primed c-DNAs resulted from unspecific priming events. This unspecific priming is likely to account for the presence of rodent clones in Alu-primed c-DNA libraries. This is consistant with the work of Corbo and coworkers who used immature transcripts from human rodent cell hybrids and identified $80 \%$ human specific clones in an Alu-primed c-DNA library [3]. In a similar library, Liu et al. recognized only $70 \%$ of the clones were of human origin [2].

RNA purification through a $\mathrm{CsCl}$ gradient did not improve the specificity of the priming reac-

Table 1. Qualitative monitoring of hn-RNA purification from human/rodent somatic cell hybrids

\begin{tabular}{llllll}
\hline Somatic cell hybrid & Background & $\begin{array}{l}\text { Selected human } \\
\text { chromosome }\end{array}$ & $\begin{array}{l}\text { Yield of hn-RNA } \\
\text { per } 5 \times 10^{6} \text { cells } \\
{[\mu \mathrm{g}]}\end{array}$ & $\begin{array}{l}\text { Yield of hn-RNA } \\
\text { following oligo-(dT) } \\
\text { purification } \\
{[\mu \mathrm{g}]}\end{array}$ & $\begin{array}{l}\text { Yield of hn-RNA } \\
\text { following a second } \\
\text { oligo-(dT) purification } \\
{[\mu \mathrm{g}]}\end{array}$ \\
\hline MCH262A1D6 & Mouse & 6 & 42 & n.d. & n.d. \\
MCH381.2D & Mouse & 6 & 90 & $14(15 \%)$ & n.d. \\
D113JA & Hamster & 6 & 72 & $4.1(5.8 \%)$ & $1.2(1.7 \%)$ \\
GM10027 & Hamster & 22 & 48 & $3.6(7.4)$ & n.d. \\
GM10888 & Hamster & 22 & 71 & & $1.4(2 \%)$ \\
\hline
\end{tabular}

n.d. not determined. 
Table 2. Yield of c-DNA prepared from somatic cell hybrids and percentage of unspecific priming

\begin{tabular}{lll}
\hline Somatic cell hybrid & $\begin{array}{l}\text { Yield of } 1 \text { strand c-DNA } \\
\text { per } 5 \mu \mathrm{g} \mathrm{hn} \text {-RNA } \\
{[\mathrm{ng}]}\end{array}$ & $\begin{array}{l}\text { Ratio of unspecific priming/ } \\
\text { Alu-priming } \\
{[\%]}\end{array}$ \\
\hline $\begin{array}{l}\text { MCH262A1D6 } \\
\text { (unpurified hn-RNA) }\end{array}$ & 80 & 16 \\
$\begin{array}{l}\text { MCH381.2D } \\
\quad \text { (poly-(dT)-purification of hn-RNA) }\end{array}$ & 640 & 2 \\
$\begin{array}{l}\text { D113JA } \\
\text { (poly-(dT)-purification of hn-RNA) }\end{array}$ & 570 & 5 \\
\hline
\end{tabular}

tion. Alternatively, hn-RNA from human rodent hybrids was purified by oligo-(dT)-cellulose affinity chromatography. Following purification we recovered between $5.8 \%$ and $15 \%$ of the hnRNA. As shown in Table 1 hybrid MCH381.2D yielded $14 \mu \mathrm{g}$ hn-RNA per $5 \times 10^{6}$ cells following poly-T-purification. This hybrid contains del(6)q21-q23. Significantly less hn-RNA $(4.1 \mu \mathrm{g})$ was recovered from hybrid D113JA which contains a chromosome 6 as its only human component. These results further suggest the significant variation of individual hybrids which must be controlled in individual experiments.

Following a second poly-T-purification the yield was reduced to $1.2 \mu \mathrm{g}$ of the hn-RNA from hybrid D113JA. This amount was equivalent to $1.7 \%$ of the originally isolated hn-RNA. A similar yield was obtained for hybrid GM10888. After a second poly-T-purification $2 \%$ of the hn-RNA was recovered (Table 1).

Subsequently, hn-RNA which was purified by poly-(dT)-columns was used for Alu-primed c-DNA synthesis. The percentage of unspecific primed c-DNA was reduced to $2 \%$ and $5 \%$ in hybrids MCH381.2D and D113J, respectively (Table 2). Interestingly, total yield of Alu-primed c-DNA was increased 7-8 fold following poly(dT)-purification.

To summarize, purified hn-RNA from somatic cell hybrids has been used to establish human specific c-DNA libraries. Importantly, the use of oligo-(dT)-purification of hn-RNA significantly reduces the percentage of unspecific priming events. In previous studies rodent clones limited the value of Alu-primed chromosome specific cDNA libraries. Our work demonstrates that enrichment of poly-A-hn-RNA sequences will greatly increase the usefulness of chromosome specific c-DNA libraries.

\section{References}

1. Jones $\mathrm{KW}$, Chevrette $\mathrm{M}$, Shapero $\mathrm{MH} \&$ Fournier RE (1992) Nature Genetics 1: 278-283

2. Liu P, Legerski R \& Siciliano MJ (1989) Science 246: 813-815

3. Corbo L, Maley JA, Nelson DL \& Caskey CT (1990) Science 249: 652-655

4. Baens M, Chaffanet M, Cassiman JJ, van den Berghe H \& Marynen P (1993) Genomics 16: 214-218

5. Meese UE, Witkowski CM, Zoghbi HY, Stanbridge EJ, Meltzer PS \& Trent JM (1992) Genomics 12: 542-548

6. Dowdy S, Scanlon D, Fasching C, Casey L \& Stanbridge E (1990) Genes Chrom. Cancer 2: 318-327

7. Chomczynski P \& Sacchi N (1987) Anal. Biochem. 162: $156-159$

8. Sambrook J, Fritsch EF \& Maniatis T (1989) Molecular cloning - A laboratory manual. Cold Spring Harbor Laboratory Press

9. Aviv H \& Leder P (1972) Proc. Natl. Acad. Sci USA 69: 1408

10. Gubler U \& Hoffmann BJ (1983) Gene 25: 263-269

11. Brooks-Wilson AR, Groodfellow PN, Povey S, Nevanlinna HA, De-Jong PJ \& Goodfellow PJ (1990) Genomics 7: 614-620

12. Meese EU, Meltzer PS, Ferguson PW \& Trent JM (1992) Genomics 12: 549-554 